\title{
Long-Term in Situ Oxidation of Biogenic Uraninite in an Alluvial Aquifer: Impact of Dissolved Oxygen and Calcium
}

\author{
Juan S. Lezama-Pacheco, ${ }^{\dagger, \text { II }}$ José M. Cerrato, ${ }^{\S, \pm}$ Harish Veeramani, ${ }^{\ddagger} \perp$ Daniel S. Alessi, ${ }^{\ddagger}, \infty$ \\ Elena Suvorova, ${ }^{\ddagger}$ Rizlan Bernier-Latmani, ${ }^{\ddagger}$ Daniel E. Giammar, ${ }^{\S}$ Philip E. Long, ${ }^{\|}$Kenneth H. Williams, $"$ \\ and John R. Bargar*, ${ }^{\dagger}$ \\ ${ }^{\dagger}$ Stanford Synchrotron Radiation Lightsource, SLAC, 2575 Sand Hill Road, Menlo Park, California 94025, United States \\ ${ }^{\ddagger}$ Environmental Microbiology Laboratory, École Polytechnique Fédérale de Lausanne, Lausanne, CH 1015, Switzerland \\ ${ }^{\S}$ Department of Energy, Environmental, and Chemical Engineering, Washington University, One Brookings Drive, Saint Louis, \\ Missouri 63130, United States \\ "Earth Science Division, Lawrence Berkeley National Laboratory, Berkeley, California 94720, United States
}

\section{Supporting Information}

\begin{abstract}
Oxidative dissolution controls uranium release to (sub)oxic pore waters from biogenic uraninite produced by natural or engineered processes, such as bioremediation. Laboratory studies show that uraninite dissolution is profoundly influenced by dissolved oxygen (DO), carbonate, and solutes such as $\mathrm{Ca}^{2+}$. In complex and heterogeneous subsurface environments, the concentrations of these solutes vary in time and space. Knowledge of dissolution processes and kinetics occurring over the long-term under such conditions is needed to predict subsurface uranium behavior and optimize the selection and performance of uraninite-based

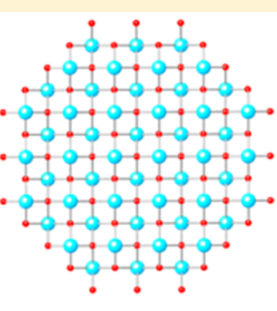

Nano-uraninite

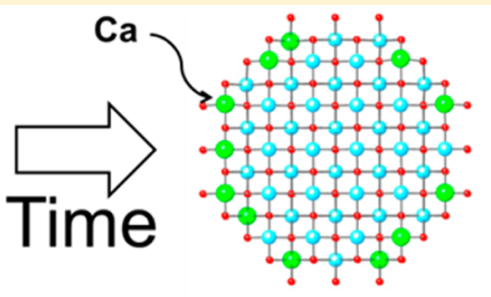

Groundwater-reacted uraninite remediation technologies over multiyear periods. We have assessed dissolution of biogenic uraninite deployed in wells at the Rifle, CO, DOE research site over a 22 month period. Uraninite loss rates were highly sensitive to DO, with near-complete loss at $>0.6 \mathrm{mg} / \mathrm{L}$ over this period but no measurable loss at lower DO. We conclude that uraninite can be stable over decadal time scales in aquifers under low DO conditions. U(VI) solid products were absent over a wide range of DO values, suggesting that dissolution proceeded through complexation and removal of oxidized surface uranium atoms by carbonate. Moreover, under the groundwater conditions present, $\mathrm{Ca}^{2+}$ binds strongly to uraninite surfaces at structural uranium sites, impacting uranium fate.
\end{abstract}

\section{INTRODUCTION}

Uraninite is produced during in situ bioreduction of soluble $\mathrm{U}(\mathrm{VI})$ to less soluble $\mathrm{U}(\mathrm{IV})$ to attenuate dissolved uranium in groundwater. $^{1-3}$ Uraninite also occurs naturally in shallow sulfidic aquifer sediments, ${ }^{4}$ where its slow dissolution may help to maintain uranium contaminant plumes. In ore deposits, uraninite stability during oxidative leaching is of economic and environmental consequence. ${ }^{5}$ Noncrystalline forms of U$(\mathrm{IV})^{6-9}$ are also produced in natural sediments and often cooccur with uraninite. ${ }^{2,6,10}$ However, these forms of U(IV) appear to be significantly less stable than uraninite. ${ }^{11}$ Where it is present in such mixtures, uraninite is likely to exert control over uranium release from sediments over the long-term. Under controlled laboratory conditions, uraninite dissolution is accelerated orders of magnitude by dissolved oxygen (DO). ${ }^{12}$ Groundwater naturally contains DO, and uraninite oxidation is therefore expected to be of broad and acute scientific importance to fate and transport of uranium in contaminated aquifers. Uraninite oxidation also is likely to mediate environmental impacts of in situ uranium leach recovery from shallow ores, $^{5,13}$ and is a potential uranium release mechanism from nuclear fuel interned in cooling ponds or geologic repositories. $^{14,15}$

Aquifers exhibit substantial variations in DO laterally and vertically. In addition, temporal $\mathrm{DO}$ variations arise following cessation of remediation treatments (DO rebound) and seasonal watershed dynamics. At the Rifle, CO, DOE field research site, the location of field-scale in situ bioremediation studies using acetate as an exogenous electron donor, ${ }^{16} \mathrm{DO}$ varies between a low of $<0.1 \mathrm{mg} / \mathrm{L}$ during fall and winter, and a high of ca. $1.5 \mathrm{mg} / \mathrm{L}$ during spring/summer meltwater runoff in wells used for this investigation. This variability confounds efforts to quantitatively model uranium behavior. While uraninite dissolution is expected to proceed under these conditions, uranium loss rates under naturally variable aquifer conditions over the long-term (multiple seasons) previously have not been reported. The chemical products of long-term

Received: February 22, 2015

Revised: May 15, 2015

Accepted: May 22, 2015

Published: May 22, 2015 
uraninite oxidation in the field in shallow groundwater also have not been reported. Moreover, the molecular-scale mechanisms that help accelerate and inhibit uraninite dissolution in the field, such as reaction with carbonate and $\mathrm{Ca}^{2+}$, respectively, have not yet been detailed.

Oxidation of biogenic nanouraninite, the focus of this investigation, has been studied in the laboratory. ${ }^{12,17-29}$ Dissolved carbonate promotes uraninite dissolution at nearneutral $\mathrm{pH}^{30}$ Under low DO conditions, oxidized $\mathrm{U}$ at uraninite surfaces can be complexed by aqueous carbonate, ${ }^{31,32}$ allowing uraninite dissolution to proceed without the accumulation of uranyl corrosion products. However, if DO is sufficiently high, then solid-phase uranyl corrosion products may accumulate as uraninite is oxidized. Rifle groundwater contains abundant bicarbonate and $\mathrm{Ca}^{2+}\left(\mathrm{ca} .5\right.$ to $\left.10 \mathrm{mM}^{16}\right)$. At the intermediate DO levels observed at the site (i.e., 0.6-1.5 $\mathrm{mg} / \mathrm{L}$ ) it is plausible that such behavior could occur, producing uranyl corrosion products such as schoepite $\left(\left(\mathrm{UO}_{2}\right)_{8} \mathrm{O}_{2}(\mathrm{OH})_{12} \cdot 12\left(\mathrm{H}_{2} \mathrm{O}\right)\right.$, tyuyamunite $\left(\mathrm{Ca}\left(\mathrm{UO}_{2}\right)_{2} \mathrm{~V}_{2} \mathrm{O}_{8}\right.$. $\left.\mathrm{H}_{2} \mathrm{O}\right)$, or liebigite $\left(\mathrm{Ca}_{2}\left(\mathrm{UO}_{2}\right)\left(\mathrm{CO}_{3}\right)_{3} \cdot 11 \mathrm{H}_{2} \mathrm{O}\right) \cdot{ }^{18,33}$ Secondary products were not observed following a short-term (83-day) uraninite oxidation experiment in Rifle wells, ${ }^{31}$ although the recovered samples were found to be enriched in $\mathrm{Ca}^{2+}$. However, that study was too short to be representative of long-term conditions. A longer-term experiment that transected complete annual cycles, including higher-DO summer conditions, and allowed a large fraction of the initial product to dissolve was required to assess the importance of secondary products under field conditions.

Campbell and co-workers ${ }^{31}$ showed that $\mathrm{Ca}^{2+}$ was strongly associated with uraninite following 83 days of submersion in groundwater in wells, but did not identify the mode of association. In a subsequent laboratory study, Cerrato and coworkers $^{18}$ showed that oxidative uraninite dissolution in controlled simple aqueous solutions (not Rifle groundwater) was 7-fold slower in the presence of $\mathrm{Ca}^{2+}$ and attributed this inhibitory effect to $\mathrm{Ca}^{2+}$ adsorption on uraninite, suggesting that a coating of uranyl- $\mathrm{Ca}^{2+}$-carbonate had precipitated. The presence of such coatings could significantly extend the lifetime of biogenic uraninite in groundwater. Significantly, the physical mechanism of $\mathrm{Ca}^{2+}$ association with uraninite under aquifer conditions has not been conclusively resolved.

The objectives of this study were (i) to assess the impact of variable dissolved oxygen conditions present in the field on uraninite oxidation mechanisms and cumulative loss rates and (ii) to evaluate the structural basis by which $\mathrm{Ca}^{2+}$ (and by extension, other alkaline earths such as $\mathrm{Mg}^{2+}$ ) associates with uraninite under field conditions. To achieve this goal, biogenic uraninite was deployed into groundwater in wells over a 22 month interval at the Rifle site, and subsequently retrieved for analysis of uranium content, oxidation state, and local molecular-scale structure around $\mathrm{Ca}$ and $\mathrm{U}$.

\section{METHODS}

Rifle, CO Field Site. Detailed information about the Rifle site is published elsewhere. ${ }^{16,31}$ The wells used in this study for uraninite incubations were chosen to bracket a range of DO concentrations. The groundwater in well B-02 varies seasonally between ca. $0.2 \mathrm{mg} / \mathrm{L}$ in fall/winter and $1.5 \mathrm{mg} / \mathrm{L}$ during summer/spring meltwater runoff. We refer to B-02 here as the "intermediate DO well". In contrast well P-103, named here as the "low DO well", varies between $<0.1$ and ca. $0.6 \mathrm{mg} / \mathrm{L} \mathrm{DO}$ (Supporting Information, SI, Table S1).
Safety. Proposed experiments were reviewed by the DOE site steward (DOE Office of Legacy Management) and approved by the U.S. Environmental Protection Agency, Region 8 prior to carrying out the activity. Uranium was amended to nonpotable groundwater during these operations. The amendment was negligible compared to the extant subsurface inventory and was diluted well below the UMTRCA Title I standard $(0.044 \mathrm{mg} / \mathrm{L})$ during the course of the experiment.

Biogenic Uraninite Synthesis. Biogenic uraninite was precipitated by Shewanella oneidensis strain MR-1, as described previously $^{31}$ and in the SI. The solid was soaked in anoxic $1 \mathrm{M}$ $\mathrm{NaOH}$ overnight to destroy associated biomass. Subsequently, the solids were iteratively washed in hexane and $100 \mathrm{mM}$ $\mathrm{NaHCO}_{3}$ to eliminate residual biomass and $\mathrm{U}(\mathrm{VI})$ until the $\mathrm{pH}$ returned to circumneutral (typically 5 to 10 iterations). Electron microscopy measurements showed the resulting cleaned nanoparticles had particle sizes of 1.5 to $2 \mathrm{~nm}^{31}$

X-ray diffraction measurements cannot be performed on gel pucks because of the large X-ray background scattered from the gels. Also, the EXAFS data quality from gel pucks is poor in comparison to an ungelled sample. Conversely, the ungelled samples for X-ray diffraction and EXAFS analysis are not suitable for quantifying total U. For this reason, uraninite was deployed in the field in permeable sample cells in two physical forms: (i) as free suspensions for subsequent spectroscopic and $\mathrm{X}$-ray scattering analyses, and (ii) as polyacrylamide gel pucks ${ }^{31}$ doped with uraninite, which were necessary for quantifying uranium mass loss. In both cases, uraninite was present in loose agglomerations. $^{31}$

Biogenic Uraninite-Doped Gel Pucks for Mass Balance. Polyacrylamide gels acted as an inert matrix that did not dissolve or chemically modify uraninite reactivity. ${ }^{31,34}$ Biogenic uraninite was homogeneously distributed within the gel puck, with an average variation of $10 \%$ between different $\mathrm{mm}$-sized pieces of the same gel and duplicate gels containing the same quantity of biogenic $\mathrm{UO}_{2}$. One half of each puck was retained to determine total $U$ loading per unit weight of each gel. A fraction of the other half was cut into slabs (approximately $2 \mathrm{~cm} \times 3 \mathrm{~mm} \times 2 \mathrm{~mm}$ ) and transferred to a sample cell (described below) for deployment.

Permeable Sample Cells, Assembly, and Deployment. Permeable sample cells $(2 \mathrm{~mL}$ volume with cellulose ester membranes) were described in detail previously. ${ }^{31}$ Suspensions of uraninite $(\sim 50$ to $300 \mathrm{mg}$ of uraninite per sample cell) or polyacrylamide gel pucks $(\sim 10-20 \mathrm{mg}$ uraninite per sample cell, for mass balance), all in ultrapure water (initial resistivity $>18.2 \mathrm{M} \Omega-\mathrm{cm}$ ), were installed into the cells in the field in a $\mathrm{N}_{2}$ filled anaerobic chamber. Uraninite samples were not preequilibrated with Rifle GW. The cells were deployed about $5 \mathrm{~m}$ below the ground surface and at least $1 \mathrm{~m}$ below the water table for the duration of the experiment. Transport of oxygen and uranium in and out of the cells is controlled by diffusion. In laboratory tests with these cells under advective flow of oxic water with bicarbonate, diffusive control caused a 140-fold decrease in uranium loss rates relative to a continuously stirred flow-through system. ${ }^{19}$

Uraninite was deployed into the "low" and "intermediate DO” wells (P-103 and B-02, respectively) on July 16, 2009. Uraninite was harvested from both wells on Oct 26, 2009 (102 days reaction), ${ }^{31}$ April 13, 2010 (271 days of reaction) and May 21, 2011 (674 days). 
Gel Puck Digestions. Gels were dried overnight at $70{ }^{\circ} \mathrm{C}$, weighed, and digested in $5 \mathrm{~mL}$ of concentrated $\mathrm{HNO}_{3}$. Dissolved U was measured by ICP-OES (PerkinElmer, Plasma 2000). Uranium content was normalized against dry gel mass. $\mathrm{U}$ loss (relative to the initial mass on each gel) was taken to be difference in $U$ concentration in gels before and after deployment. Digestions were complemented by SEM-EDS measurements.

Characterization of Biogenic Uraninite. Particle morphology, crystallinity, phase identity, molecular structure around $\mathrm{U}$ and $\mathrm{Ca}$, and the composition of uraninite recovered from the slurry-filled sample cells after in situ reaction were determined by scanning transmission electron microscopy (STEM), X-ray diffraction (XRD), X-ray absorption near edge structure (XANES), extended X-ray absorption fine structure (EXAFS), and chemical digestion. Data collection and analysis operations are described in the SI.

\section{RESULTS AND DISCUSSION}

Uranium Loss Rate. Figure 1 and SI Table S1 show that groundwater DO values varied by a factor of 5 between fall/ winter (low DO) and spring/summer (high DO). High discharge during spring/summer meltwater events causes the water table to rise locally and groundwater to exhibit higher DO values. Consequently, we expect the greatest uraninite dissolution to occur seasonally, during spring/summer. In spite of this behavior, no statistically significant loss of uranium was observed in well P-103 ("low DO" well) throughout the experiment. The highest concentration of DO recorded in this well was $0.56 \mathrm{mg} / \mathrm{L}$. We conclude that uraninite dissolution is negligible in Rifle groundwater as long as DO remains below ca $0.6 \mathrm{mg} / \mathrm{L}$ during the summer meltwater event and below ca 0.3 $\mathrm{mg} / \mathrm{L}$ during the rest of the year. Under these conditions, uraninite is expected to persist for decades.

In well B-02, DO was $1.2 \mathrm{mg} / \mathrm{L}$ at the start of the experiment (July 16, 2009), which occurred during the 2009 spring/ summer meltwater event. Gel pucks that were recovered on Oct 26, 2009 (102 days after the start of the experiment) had lost $55 \%$ of their original uranium. Groundwater composition in this well is similar to that in P-103, with the exception that DO concentrations were much higher in B- 02 . We conclude that DO caused oxidative dissolution of uraninite to occur in well B-02 under spring/summer groundwater conditions. During the subsequent fall-winter period (Oct 26, 2009 April 13, 2010), measured DO values in well B-02 were $<0.6$ $\mathrm{mg} / \mathrm{L}$. On the basis of the results from the P-103 well, no additional uraninite loss is expected to have occurred under these DO conditions, and none was recorded over this interval. Indeed, the measured uranium loss for the B-02 gel pucks on April 13, 2010 (271 days) relative to their original amounts was actually $31 \%$. Because it is not physically possible for the amount of uraninite present to have increased during the incubation, we attribute the apparent increase in uraninite between Oct 26, 2009 and April 13, 2010 to uncertainty inherent in the method. During the remaining year of the experiment (April 13, 2010 to May 21, 2011), the samples traversed the $2010 \mathrm{spring} /$ summer meltwater/high DO event, and the first portion of the 2011 meltwater event. Over this period, the amount of uranium lost climbed to $90 \%$ (674 days) relative to the amount at the start of the experiment. This comparison suggests that in-well uraninite oxidation rates are highly sensitive to the amount and duration of DO present during the spring/summer period. Under intermediate DO

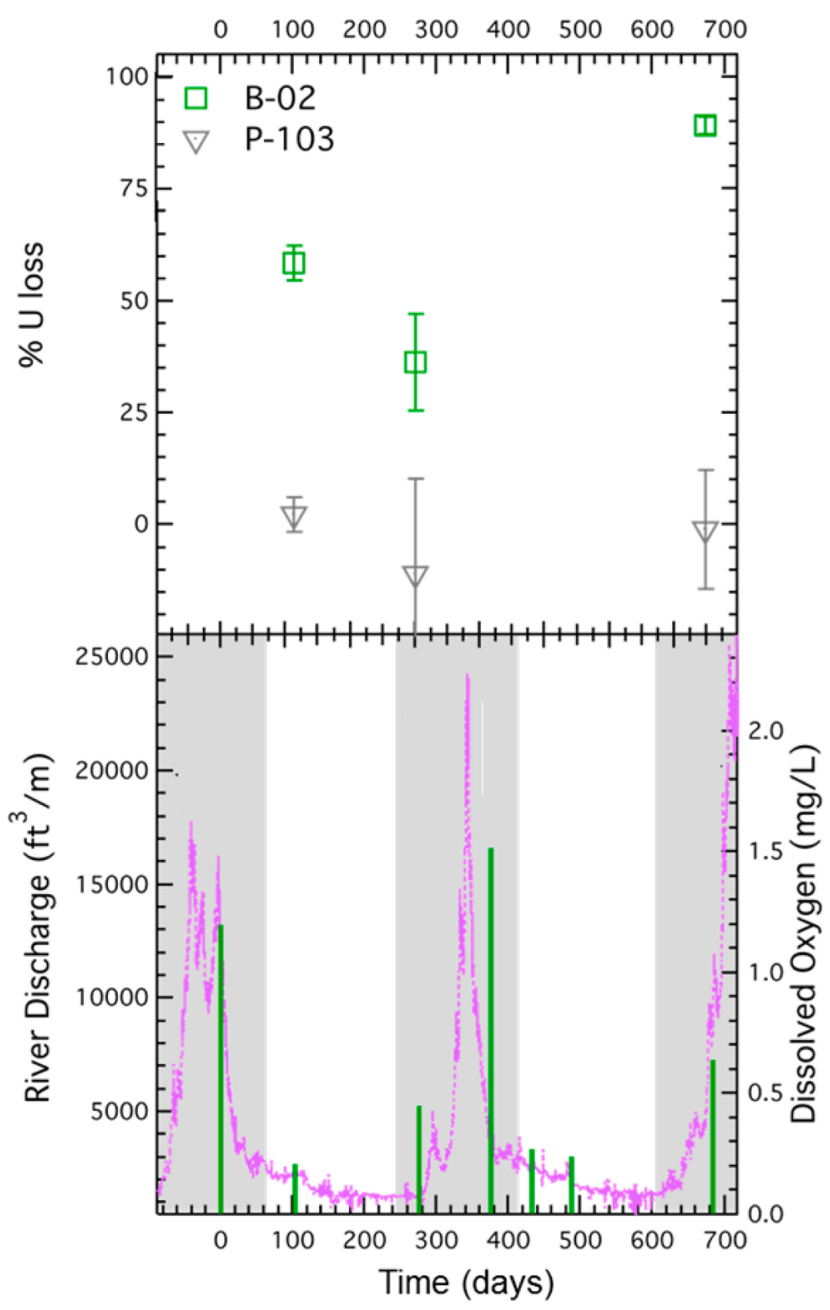

Figure 1. Top: U losses from gel pucks deployed in Rifle wells as a function of reaction time. Uncertainty is the standard deviation from triplicate measurements of gel pucks (cf., Methods). In well P103, which had low DO, no statistically significant uranium loss was observed. However, in well B-02, which had intermediate concentrations of DO, approximately $90 \%$ of uraninite was lost after 674 days of reaction. Bottom: DO values recorded (green bars) in well B-02 compared to the hydraulic discharge of the Colorado River (purple dashed line) just below Glenwood springs, CO (USGS monitoring site 9085100). Spring/summer periods, when discharges reach maxima, are marked in gray. DO values obtain their highest levels during meltwater discharge. Uranium oxidation rates are expected to be highest at these times. In contrast, uraninite oxidation is expected to be relatively slow during the intervening fall/winter periods.

conditions in Rifle groundwater (i.e., $0.6-1.5 \mathrm{mg} / \mathrm{L}$ during spring/summer), biogenic uraninite can be expected to persist for only a few years.

Association of $\mathrm{Ca}^{2+}$ with Uraninite. Chemical digestions of uraninite recovered from Rifle wells (SI Table S2) indicate groundwater solutes were present in association with uraninite. In particular, calcium accounts for ca. one-quarter of the metal atoms in the samples. A similar result was reported for uraninite recovered after 102 days in Rifle wells. ${ }^{31} \mathrm{Ca}^{2+}$ is present in Rifle groundwater at millimolar concentrations, and thus could react with the uraninite nanoparticles. The molecular-scale mechanism of association is discussed in detail below.

Effect of In-Well Reaction on Particle Morphology and Unit Cell Structure. As shown in high resolution STEM images in Figure 2 and SI Figure S1, uraninite nanoparticles 


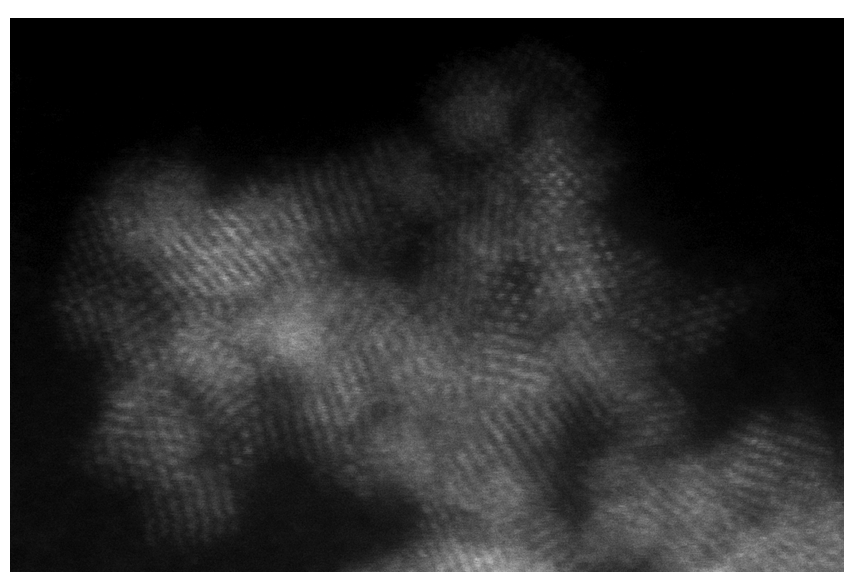

Figure 2. High resolution STEM measurements of nanouraninite after 674 days of reaction with groundwater in the intermediate DO Rifle well (B-02). The crystalline $\mathrm{UO}_{2}$ structure is observed out to the particle terminations, and no evidence is observed to support the presence of coatings or precipitates.

removed from the intermediate DO well after 674 days have well-defined lattice fringes that extend to the termini of the particles. No evidence is present for amorphous or crystalline coatings. High resolution EDS data (SI Figure S2) confirm that $\mathrm{Ca}$ is associated with uraninite nanoparticles.
XRD powder patterns of uraninite before and after reaction in Rifle wells are shown in SI Figure S3. The XRD patterns of the reacted samples are identical to one-another and similar to that of the preincubation sample. This overall similarity suggests that the unit cell and particle size are similar before and after reaction. However, following reaction in Rifle wells, the intensities of the peaks at ca. 4.5 and $7 \AA^{-1}$ are slightly different from the preincubation material. This change coincides with the EXAFS-observed increase in local structural order around $\mathrm{U}$ after incubation. No obvious additional XRD peaks are present following reaction in-well, suggesting that no new crystalline phases have formed above detection limit $(\leq 0.5$ wt $\%^{35}$ ) over the 22 -month time scale of the experiment.

Oxidation State of Uranium. As shown in SI Figure S4, U $\mathrm{L}_{\mathrm{III}}$-edge XANES for uraninite suspensions removed from the wells are similar to that of a $\mathrm{UO}_{2.00}$ reference, indicating that uranium is predominantly present as $\mathrm{U}(\mathrm{IV})$. Gel-embedded uraninite is also predominantly U(IV) (SI Figures S4 and S5).

Molecular Structure around Uranium. $\mathrm{U} \mathrm{L}_{\mathrm{II}}$-edge EXAFS spectra measured from uraninite suspensions incubated in Rifle wells are shown in Figure 3 and SI Figure S6. Fit results are reported in SI Table S3. The EXAFS spectra are qualitatively similar to one-another and exhibit prominent $\mathrm{U}-\mathrm{O}$ and $\mathrm{U}-\mathrm{U}$ pair correlations at ca. 1.8 and $3.8 \AA$ (uncorrected for phase shift) in the Fourier transforms (FTs), corresponding to interatomic distances of 2.26-2.43 (U-O)
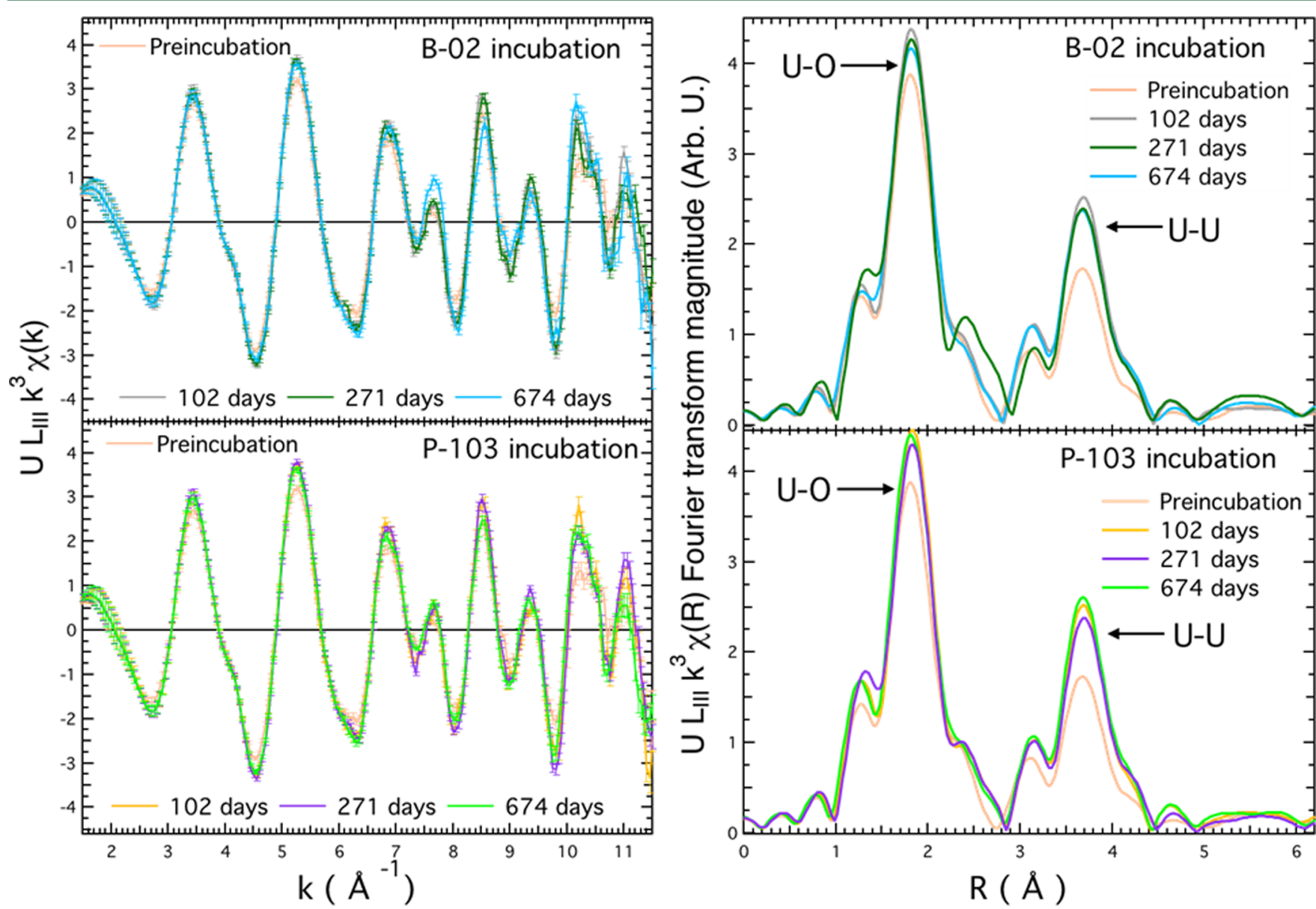

Figure 3. $\mathrm{U} \mathrm{L}_{\mathrm{III}}$ EXAFS (left) and corresponding Fourier Transforms (right) for biogenic uraninite reacted in Rifle wells. Symbols represent fits to the data. "Preincubation" corresponds to the source material for the experiments prior to reaction in Rifle wells. Incubation in Rifle wells results in an increase in the ampltidue of the $\mathrm{U}-\mathrm{U}$ pair correlation. 
and $3.83 \AA$ (U-U) (SI Table S3), as expected for the structure of uraninite. ${ }^{36}$ (The FT peak at ca. $3.1 \AA$ also arises from the $\mathrm{U}-\mathrm{U}$ pair.) Aging of samples in Rifle wells resulted in a substantial (50\%) increase in the amplitude of the U-U pair correlation, indicating an overall increase in the intermediate structural order around $U$ in atoms in uraninite. Possible explanations for this behavior include: (i) an apparent increase in structural order accomplished by preferential dissolution and removal of smaller and poorly ordered uraninite, leaving behind a more structurally ordered material, or (ii) a bona fide increase in the intermediate-range structural order around $U$ in the particles.

An increase in the amplitude of the U-U pair correlation was observed in both wells, i.e., it occurred in the low DO well where there was no significant uranium loss quantifiable with the gel pucks (vide infra). Under these conditions, explanation (i) above is inadequate, and we conclude that the change in the $\mathrm{U}-\mathrm{U}$ amplitude is due to a true increase in the intermediate structural order around U(IV) in uraninite. This conclusion is reinforced by the EXAFS fits, which show that increasing $U-U$ amplitude is associated with a decrease in the U-U DebyeWaller (disorder) parameter (SI Figure S7). Small C and P/Si shells were required to fit the data satisfactorily (SI Table S3). $\mathrm{Si}$ is detected in the EDS measurements of individual $\mathrm{UO}_{2}$ nanoparticles (SI Figure S2). Consequently, it is plausibly coordinated to terminal $\mathrm{Ca}$ atoms. The presence of $\mathrm{C}$ is attributed to residual organic matter that remained associated with the particles after the cleaning procedure.

It is possible that the change in local structure around uranium that occurred at the beginning of the experiment coincided with an increase in the stability of uraninite. This change in local structural order occurred in both wells and thus should affect all samples equally. However, such a stabilization effect does not provide an alternative explanation for the contrast in $U$ loss rates between the low and intermediate DO conditions.

Molecular Structure around Calcium. Calcite is a plausible precipitate phase, given that groundwater is close to calcite saturation. To assess if calcite or noncrystalline calcitelike solids were present, Ca K-edge EXAFS spectra (Figure 4, SI Figure S8) were measured from uraninite suspensions incubated in Rifle wells. The spectra of the in-well incubated uraninite are similar to one-another and distinct from that of calcite, indicating that calcite-like solids are minority phases or are not present. However, fits to the Ca EXAFS spectra reveal the presence of $U$ neighbors at $3.86 \AA$ (SI Table S4). In addition, fits to the data required inclusion of a carbon shell at $3.67 \AA$, suggesting the presence of carbonate groups each sharing a single $\mathrm{O}$ atom with $\mathrm{Ca}$. This observation suggests that $\mathrm{Ca}^{2+}$ is present at the surface of uraninite.

These results provide a molecular-scale explanation for the strong interaction between uraninite and $\mathrm{Ca}^{2+}$ observed in digestions. Three possible explanations can be advanced to account for this behavior: (i) $\mathrm{Ca}^{2+}$ was adsorbed to the exterior surfaces of uraninite nanoparticles; (ii) uranyl- $\mathrm{Ca}^{2+}$-carbonate solids precipitated on uraninite surfaces; ${ }^{18}$ or (iii) $\mathrm{Ca}^{2+}$ was structurally incorporated within uraninite.

We consider these explanations in turn. We can rule out the presence of uranyl precipitates or coatings of nonuraninite solids on the surfaces of uraninite based on the lack of evidence for such materials in the STEM, XRD, and EXAFS data. Moreover, XANES spectra show that only trace uranyl was present-not enough to account for the abundant $\mathrm{Ca}^{2+}$

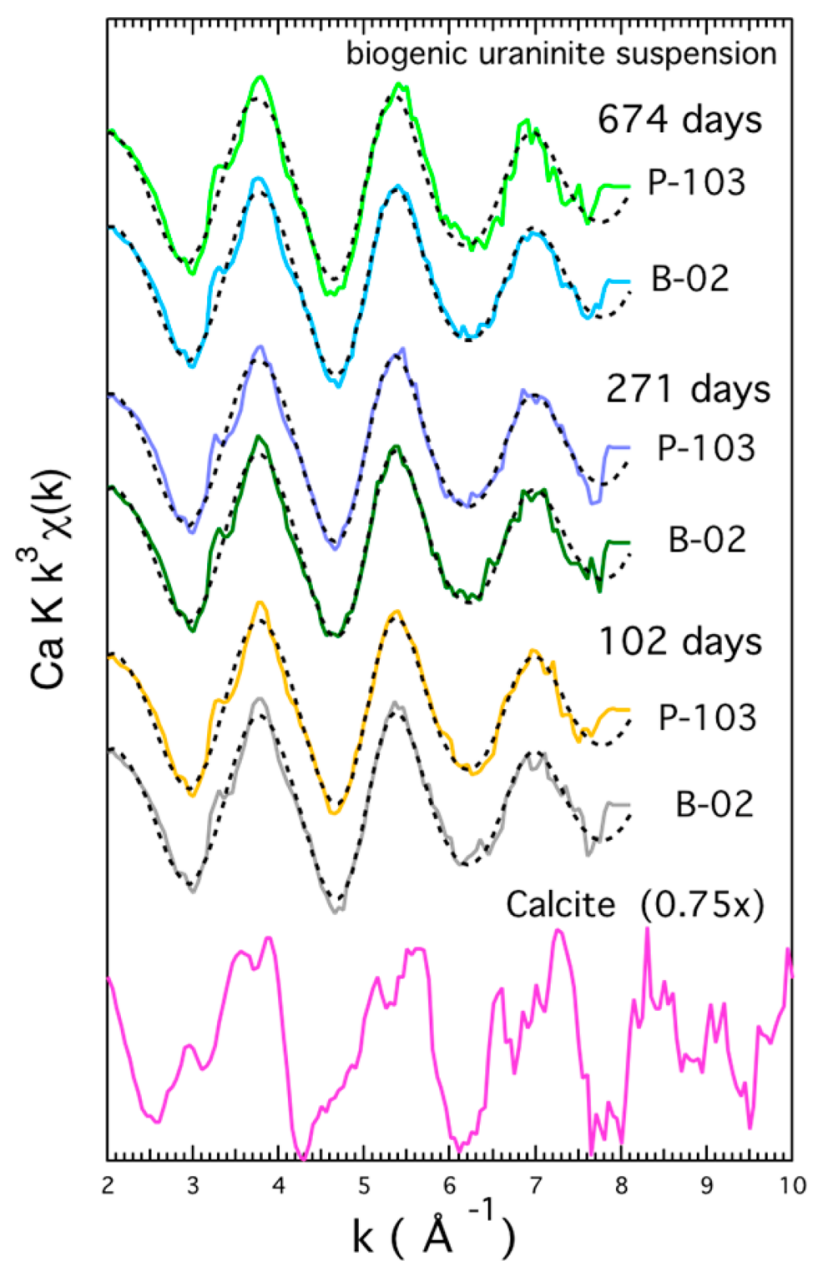

Figure 4. Ca K EXAFS for biogenic uraninite reacted in Rifle wells. Dashed lines represent fits to the data. The difference between the EXAFS spectra of the samples as compared to calcite indicates that calcite is a minor phase or is not present.

observed. Incorporation of $\mathrm{Ca}^{2+}$ within uraninite is unlikely because $>90 \%$ of the uraninite-associated $\mathrm{Ca}^{2+}$ could be desorbed from uraninite surfaces. ${ }^{31}$ Lastly, the difference in ionic radii between $\mathrm{Ca}^{2+}(1.12 \AA)$ and $\mathrm{U}^{4+}(1.00 \AA)^{37}$ suggests that incorporation of $\mathrm{Ca}^{2+}$ should be accompanied by distortion of the local structure around $U$ atoms (decreasing amplitude of U-U pair correlations in FTs) and by a loss of crystallinity (broadening and loss of XRD peak intensity), as is observed when $\mathrm{Mn}^{2+}$ substitutes into uraninite. ${ }^{38}$ No such distortions were observed in the present study. Indeed, just the opposite was observed; the local structural order around uranium in uraninite increased after reaction in the Rifle wells.

This discussion leads to the conclusion that $\mathrm{Ca}$ is present on the exterior surfaces of uraninite nanoparticles. The ratio of surface to bulk uranium sites in an oxygen-terminated $2 \mathrm{~nm}$ uraninite nanoparticle (this study) is $c a 0.8$. (i.e., nearly half of all crystallographic $U$ sites in the nanoparticle are at the surface). Full occupation of the uraninite surface sites by $\mathrm{Ca}^{2+}$ would produce overall $\mathrm{Ca}: \mathrm{U}$ ratios (i.e., in the bulk sample) approaching this value. The overall $\mathrm{Ca}: \mathrm{U}$ ratios observed in this study via digestions (Ca: $\mathrm{U}$ was 0.21 to 0.31 , cf., SI Table S2) do not exceed this maximum value and thus are consistent with a surface binding model. In contrast, a classical surface complexation model, in which adsorbing $\mathrm{Ca}^{2+}$ replaces surface protons, would predict a much lower sorption capacity of $\mathrm{Ca}^{2+}$ on 
uraninite. For example, if the sorption density of $\mathrm{Ca}^{2+}\left(\Gamma_{\mathrm{Ca}}\right)$ were to be estimated from a recent study of $\mathrm{Zn}^{2+}$ surface complexation on uraninite nanoparticles (for which sorption densities of $\Gamma_{\mathrm{Zn}} \leq 1.8 \mathrm{Zn}^{2+} / \mathrm{nm}^{2}$ were observed), ${ }^{39}$ then a surface Ca:bulk $\mathrm{U}$ ratio of 0.07 would be obtained. The upper limit on the sorption density of surface-complexed $\mathrm{Ca}\left(\Gamma_{\mathrm{Ca} \text { max }}\right)$ can be estimated by equating it to the density of proton-active surface sites, which is expected to be ca. $<4$ sites $/ \mathrm{nm}^{2} \cdot{ }^{40} \Gamma_{\mathrm{Ca} \text {,max }}$ $<4$ sites $/ \mathrm{nm}^{2}$ implies a surface Ca:bulk $U$ ratio $<0.16$. This upper limit is greatly exceeded by the observed overall $\mathrm{Ca}: \mathrm{U}$ ratios in the bulk sample. Thus, we conclude that our present results are inconsistent with a simple surface complexation mechanism of $\mathrm{Ca}^{2+}$ on uraninite. Since calcite-like phases cannot explain this behavior, we attribute the overall $\mathrm{Ca}: \mathrm{U}$ ratios to structural replacement of $\mathrm{Ca}^{2+}$ at surface uranium structural sites on particle surfaces. The presence of $\mathrm{Ca}-\mathrm{U}$ pair correlations at $3.86 \AA$ further suggests direct bonding of $\mathrm{Ca}$ to $\mathrm{UO}_{2}$ surfaces at $\mathrm{U}$ sites.

On the basis of these observations, we conclude that a model in which $\mathrm{Ca}^{2+}$ occupies uranium sites at uraninite surfaces (Figure 5) can best explain all experimental results. Calcium atoms are expected to be capped by carbonate anions (not illustrated), in accord with the Ca EXAFS results.

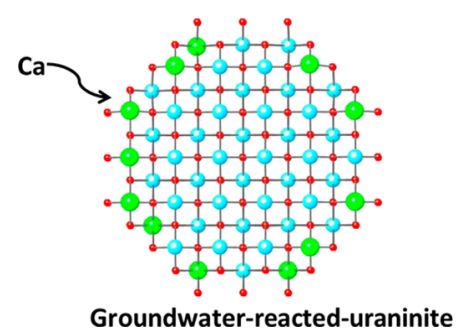

Figure 5. Conceptual model for $\mathrm{Ca}^{2+}$ binding on uraninite surfaces. A $2 \mathrm{~nm}$-diameter uraninite nanoparticle is partially surface-terminated by Ca atoms (green), which occupy structural uranium (blue) sites.

$\mathrm{Ca}^{2+}-\mathrm{UO}_{2}$ bonding provides a potential qualitative explanation for the increase in the structural order of uraninite observed after reaction with Rifle groundwater. Surface strain is believed to distort the $\mathrm{U}-\mathrm{U}$ pair in $\mathrm{UO}_{2}$ nanoparticles. ${ }^{36}$ If the U-U pair becomes more ordered, all other variables being unchanged, then it is reasonable to infer that surface strain has decreased. Moreover, bonding of foreign ions at nanoparticle surfaces has been shown to reduce nanoparticle surface strain. ${ }^{41,42}$ If the apparently strong interaction between $\mathrm{Ca}^{2+}$ and uraninite surfaces were to drive a reduction in surface strain, then an increase in structural order of the $U-U$ pair should be observed, consistent with our present results.

Uraninite Oxidation Mechanism. EXAFS, XRD, and STEM measurements show that uraninite was the primary uranium solid phase throughout the 674 day experiment under the wide range of DO conditions present. There was no evidence for accumulation of solid-phase U(VI) in the uraninite suspensions. Consequently, we conclude that uraninite dissolution under intermediate DO conditions (well B-02) occurred by the steady loss of uraninite accompanied by the formation and outward diffusion of uranyl carbonate complexes. $^{12}$

Implications. The presence of $\mathrm{Ca}^{2+}$ or other alkaline earths capping the surfaces of uraninite nanoparticles may retard reaction of uraninite nanoparticles with reactive solutes such as DO. Cerrato and co-workers ${ }^{18}$ noted that uraninite oxidative dissolution rates in simple aqueous solutions are 7 -fold lower in the presence of dissolved $\mathrm{Ca}^{2+}$. The present results suggest that strong bonding of calcium at the uraninite-water interface is a root cause for this passivation effect. We note that $\mathrm{Mg}^{2+}$ is also relatively abundant in Rifle groundwater and was associated with uraninite after reaction in the aquifer (SI Table S2). The ionic radius of $\mathrm{Mg}^{2+}(0.89)$ is reasonably matched to that of $\mathrm{U}^{4+}$. Consequently, we posit that $\mathrm{Mg}^{2+}$ could also bond tightly to uraninite surface sites, reducing the reactivity of the underlying uraninite.

The extent of uraninite loss in diffusion-limited subsurface environments is highly sensitive to DO concentration. At low DO conditions (i.e., $<0.6 \mathrm{mg} / \mathrm{L}$ during spring/summer and < ca. $0.3 \mathrm{mg} / \mathrm{L}$ fall/winter), no significant uranium dissolution occurred over a 674-day period. Bioremediation strategies that can maintain seasonally variable DO levels in groundwater (naturally or artificially) at or below those observed should in well P-103 should be effective in sequestering uranium for long periods of time (decades). Maintaining low average DO is important; At intermediate DO conditions $(0.6-1.5 \mathrm{mg} / \mathrm{L}$ during spring/summer), uraninite is expected to dissolve within a few years. Noncrystalline forms of U(IV $)^{7,9}$ are considered to be more reactive with complexing agents such as bicarbonate and oxidants than uraninite, ${ }^{11}$ and consequently may not exhibit the same degree of longevity as uraninite under maintained low DO conditions.

The sensitivity of uraninite dissolution to DO concentrations highlights the need to quantitatively understand the dependence of uraninite dissolution rates on the macroscopically observed concentration of DO over a range of DO values. Moreover, the excursions in DO values experienced seasonally must be understood at the physical location of interest within the aquifer, i.e., within pore spaces. Because of the apparently steep dependence of the oxidative dissolution rate on DO concentration, it is likely that most dissolution occurs over relatively short time periods, i.e., during "hot moments", ${ }^{43}$ when DO obtains maximum seasonal values. While this statement applies to aquifers exhibiting strong seasonal variations in $\mathrm{DO}$, these results serve as a general guide for all aquifers in which uraninite may be exposed to low levels of oxygen. If uraninite is located within secondary or tertiary pores, which is likely to be the case, then dissolution will be limited by the microscale diffusion of uranyl (away), oxygen, and/or carbonate (to uraninite), ${ }^{19}$ effectively increasing its longevity. The intrinsic reaction rates, time scales for diffusion, and periods of seasonally elevated DO are likely to overlap in complex fashions. More research is required to understand the implications of this overlap for subsurface uranium mobility.

\section{ASSOCIATED CONTENT}

Supporting Information

Additional methods, SEM images of uraninite with associated EDS analyses, XRD data and fitting results, XANES spectra, U LIII-edge and Ca K-edge EXAFS fits, and chemical extraction data. The Supporting Information is available free of charge on the ACS Publications website at DOI: 10.1021/acs.est.5b00949.

\section{AUTHOR INFORMATION}

\section{Corresponding Author}

*Phone: (650) 926-4949; fax: (650) 926-4100; e-mail: bargar@ slac.stanford.edu. 


\section{Present Addresses}

${ }^{\perp}$ Department of Earth and Environmental Sciences, University of Waterloo, Waterloo, Ontario N2L 3G1, Canada.

${ }^{\pi}$ Department of Earth and Earth System Science, Stanford University, Stanford, California 94305, U.S.A.

${ }^{ \pm}$Department of Civil Engineering, University of New Mexico, Albuquerque, NM 87106, U.S.A.

${ }^{\infty}$ Department of Earth and Atmospheric Sciences, University of Alberta, Edmonton, Alberta T6G 2E3, Canada.

\section{Notes}

The authors declare no competing financial interest.

\section{ACKNOWLEDGMENTS}

We thank Lisa Blue for fabricating the sample cells and Richard Dayvault, David Traub, Carol Morris, Ray Russ, James Allan, and the DOE office of Legacy Management for logistical support. We also thank four anonymous reviewers for their helpful insights. Funding for this project was provided to the SLAC SFA program by the DOE Office of Biological and Environmental Research, Subsurface Biogeochemistry Research (SBR) activity under contract DE-AC02-76SF00515 and to EPFL under grant DE-FG02-06ER64227. Funding was provided by Swiss NSF grants 20021-113784 and 200020$126921 / 1$. Portions of this research were carried out at the Stanford Synchrotron Radiation Light Source, a national user facility operated by Stanford University on behalf of the US DOE Office of Basic Energy Sciences.

\section{REFERENCES}

(1) Alessi, D. S.; Lezama-Pacheco, J. S.; Janot, N.; Suvorova, E. I.; Cerrato, J. M.; Giammar, D. E.; Davis, J. A.; Fox, P. M.; Williams, K. H.; Long, P. E.; Handley, K. M.; Bernier-Latmani, R.; Bargar, J. R. Speciation and reactivity of uranium products formed during in situ bioremediation in a shallow alluvial aquifer. Environ. Sci. Technol. 2014, 48 (21), 12842-12850 DOI: 10.1021/es502701u.

(2) Bargar, J. R.; Williams, K. H.; Campbell, K. M.; Long, P. E.; Stubbs, J. E.; Suvorova, E. I.; Lezama-Pacheco, J. S.; Alessi, D. S.; Stylo, M.; Webb, S. M.; Davis, J. A.; Giammar, D. E.; Blue, L. Y.; BernierLatmani, R. Uranium redox transition pathways in acetate-amended sediments. Proc. Natl. Acad. Sci. U. S. A. 2013, 110 (12), 4506-4511 DOI: $10.1073 /$ pnas.1219198110.

(3) Kelly, S.; Kemner, K. M.; Carley, J.; Criddle, C.; Jardine, P. M.; Marsh, T. L.; Phillips, D.; Watson, D.; Wu, W.-M. Speciation of uranium in sediments before and after in-situ biostimulation. Environ. Sci. Technol. 2008, 42 (5), 1558-1564 DOI: 10.1021/es071764i.

(4) Qafoku, N. P.; Gartman, B. N.; Kukkadapu, R. K.; Arey, B. W.; Williams, K. H.; Mouser, P. J.; Heal, S. M.; Bargar, J. R.; Janot, N.; Yabusaki, S.; Long, P. E. Geochemical and mineralogical investigation of uranium in multi-element contaminated, organic-rich subsurface sediment. Appl. Geochem. 2014, 42, 77-85 DOI: 10.1016/j.apgeochem.2013.12.001.

(5) Pastukhov, A. M.; Rychkov, V. N.; Smirnov, A. L.; Skripchenko, S. Y.; Poponin, N. A. Purification of in situ leaching solution for uranium mining by removing solids from suspension. Miner. Eng. 2014, 55, 1-4 DOI: 10.1016/j.mineng.2013.09.007.

(6) Alessi, D. S.; Lezama-Pacheco, J. S.; Stubbs, J. E.; Janousch, M.; Bargar, J. R.; Persson, P.; Bernier-Latmani, R. The product of microbial uranium reduction includes multiple species with $\mathrm{U}(\mathrm{IV})$ - phosphate coordination. Geochim. Cosmochim. Acta 2014, 131, 115-127 DOI: $10.1016 /$ j.gca.2014.01.005.

(7) Bernier-Latmani, R; Veeramani, H.; Vecchia, E. D.; Junier, P.; Lezama-Pacheco, J. S.; Suvorova, E. I.; Sharp, J. O.; Wigginton, N. S.; Bargar, J. R. Non-uraninite products of microbial U(VI) reduction. Environ. Sci. Technol. 2010, 44 (24), 9456-9462 DOI: 10.1021/ es101675a.
(8) Boyanov, M. I.; Fletcher, K. E.; Kwon, M. J.; Rui, X.; O’Loughlin, E. J.; Loffler, F. E.; Kemner, K. M. Solution and microbial controls on the formation of reduced U(IV) species. Environ. Sci. Technol. 2011, 45 (19), 8336-8344 DOI: 10.1021/es2014049.

(9) Fletcher, K. E.; Boyanov, M. I.; Thomas, S. H.; Wu, Q. Z.; Kemner, K. M.; Loffler, F. E. U(VI) reduction to mononuclear U(IV) by Desulfitobacterium species. Environ. Sci. Technol. 2010, 44 (12), 4705-4709 DOI: 10.1021/es903636c.

(10) Campbell, K. M.; Kukkadapu, R. K.; Qafoku, N. P.; Peacock, A. D.; Lesher, E.; Williams, K. H.; Bargar, J. R.; Wilkins, M. J.; Figueroa, L.; Ranville, J.; Davis, J. A.; Long, P. E. Geochemical, mineralogical and microbiological characteristics of sediment from a naturally reduced zone in a uranium-contaminated aquifer. Appl. Geochem. 2012, 27 (8), 1499-1511 DOI: 10.1016/j.apgeochem.2012.04.013.

(11) Alessi, D. S.; Uster, B.; Veeramani, H.; Suvorova, E.; LezamaPacheco, J. S.; Stubbs, J. E.; Bargar, J. R.; Bernier-Latmani, R. Quantitative separation of monomeric $\mathrm{U}(\mathrm{IV})$ from $\mathrm{UO}_{2}$ in products of U(VI) reduction. Environ. Sci. Technol. 2012, 46 (11), 6150-6157 DOI: $10.1021 /$ es204123z.

(12) Ulrich, K.-U.; Ilton, E. S.; Veeramani, H.; Sharp, J. O.; BernierLatmani, R.; Schofield, E. J.; Bargar, J. R.; Giammar, D. E. Comparative dissolution kinetics of biogenic and chemogenic uraninite under oxidizing conditions in the presence of carbonate. Geochim. Cosmochim. Acta 2009, 73 (20), 6065-6083 DOI: 10.1016/ j.gca.2009.07.012.

(13) Finch, R.; Murakami, T., Systematics and paragenesis of uranium minerals In Uranium: Mineralogy, Geochemistry and the Environment. Reviews in Mineralogy; Burns, P. C., Finch, R. J., Eds.; Mineralogical Society of America: Washington, D.C., 1999; Vol. 38; pp 89-179.

(14) Ewing, R. C., Radioactivity and the 20th Century. In Uranium: Mineralogy, Geochemistry, and the Environment. Review in Mneralogy; Burns, P. C., Finch, R., Eds.; Mineralogical Society of America: Washington, D.C., 1999, Vol. 38; pp 1-22.

(15) Shoesmith, D. W. Fuel corrosion processes under waste disposal conditions. J. Nucl. Mater. 2000, 282 (1), 1-31 DOI: 10.1016/S00223115(00)00392-5.

(16) Williams, K. H.; Long, P. E.; Davis, J. A.; Wilkins, M. J.; N'Guessan, A. L.; Steefel, C. I.; Yang, L.; Newcomer, D.; Spane, F. A.; Kerkhof, L. J.; McGuinness, L.; Dayvault, R.; Lovley, D. R. Acetate availability and its influence on sustainable bioremediation of uraniumcontaminated groundwater. Geomicrobiol. J. 2011, 28 (5-6), 519-539 DOI: $10.1080 / 01490451.2010 .520074$.

(17) Cerrato, J. M.; Ashner, M. N.; Alessi, D. S.; Lezama-Pacheco, J. S.; Bernier-Latmani, R.; Bargar, J. R.; Giammar, D. E. Relative reactivity of biogenic and chemogenic uraninite and biogenic noncrystalline U(IV). Environ. Sci. Technol. 2013, 47 (17), 97569763 DOI: $10.1021 /$ es401663t.

(18) Cerrato, J. M.; Barrows, C. J.; Blue, L. Y.; Lezama-Pacheco, J. S.; Bargar, J. R.; Giammar, D. E. Effect of $\mathrm{Ca}^{2+}$ and $\mathrm{Zn}^{2+}$ on $\mathrm{UO}_{2}$ dissolution rates. Environ. Sci. Technol. 2012, 46 (5), 2731-2737 DOI: $10.1021 /$ es203751t.

(19) Giammar, D. E.; Cerrato, J. M.; Mehta, V.; Wang, Z.; Wang, Y.; Pepping, T. J.; Ulrich, K.-U.; Lezama-Pacheco, J. S.; Bargar, J. R. Effect of diffusive transport limitations on $\mathrm{UO}_{2}$ dissolution. Water Res. 2012, 46 (18), 6023-6032 DOI: 10.1016/j.watres.2012.08.034.

(20) Ulrich, K. U.; Singh, A.; Schofield, E. J.; Bargar, J. R.; Veeramani, H.; Sharp, J. O.; Bernier-Latmani, R.; Giammar, D. E. Dissolution of biogenic and synthetic $\mathrm{UO}_{2}$ under varied reducing conditions. Environ. Sci. Technol. 2008, 42 (15), 5600-5606 DOI: 10.1021/es800647u.

(21) Bi, Y.; Hayes, K. F. Surface passivation limited $\mathrm{UO}_{2}$ oxidative dissolution in the presence of FeS. Environ. Sci. Technol. 2014, 48 (22), 13402-13411 DOI: $10.1021 /$ es5041392.

(22) Wang, Z.; Tebo, B. M.; Giammar, D. E. Effects of Mn(II) on $\mathrm{UO}_{2}$ dissolution under anoxic and oxic conditions. Environ. Sci. Technol. 2014, 48 (10), 5546-5554 DOI: 10.1021/es5002067.

(23) Wang, Z.; Xiong, W.; Tebo, B. M.; Giammar, D. E. Oxidative $\mathrm{UO}_{2}$ dissolution induced by soluble $\mathrm{Mn}(\mathrm{III})$. Environ. Sci. Technol. 2014, 48 (1), 289-298 DOI: 10.1021/es4037308. 
(24) Yang, Z.; Kang, M.; Ma, B.; Xie, J.; Chen, F.; Charlet, L.; Liu, C. Inhibition of $\mathrm{U}(\mathrm{VI})$ reduction by synthetic and natural pyrite. Environ. Sci. Technol. 2014, 48 (18), 10716-10724 DOI: 10.1021/es502181x.

(25) Bi, Y.; Hayes, K. F. Nano-FeS inhibits $\mathrm{UO}_{2}$ reoxidation under varied oxic conditions. Environ. Sci. Technol. 2014, 48 (1), 632-640 DOI: $10.1021 / \mathrm{es} 4043353$.

(26) Stewart, B. D.; Girardot, C.; Spycher, N.; Sani, R. K.; Peyton, B. $\mathrm{M}$. Influence of chelating agents on biogenic uraninite reoxidation by Fe(III) (hydr)oxides. Environ. Sci. Technol. 2013, 47 (1), 364-371 DOI: $10.1021 /$ es303022p.

(27) Ginder-Vogel, M.; Stewart, B.; Fendorf, S. Kinetic and mechanistic constraints on the oxidation of biogenic uraninite by ferrihydrite. Environ. Sci. Technol. 2010, 44 (1), 163-169 DOI: $10.1021 /$ es $902452 \mathrm{u}$.

(28) Chinni, S.; Anderson, C. R.; Ulrich, K.-U.; Giammar, D. E.; Tebo, B. M. Indirect $\mathrm{UO}_{2}$ oxidation by $\mathrm{Mn}$ (II)-oxidizing spores of Bacillus sp strain SG-1 and the effect of $\mathrm{U}$ and $\mathrm{Mn}$ concentrations. Environ. Sci. Technol. 2008, 42 (23), 8709-8714 DOI: 10.1021/ es801388p.

(29) Ginder-Vogel, M.; Criddle, C. S.; Fendorf, S. Thermodynamic constraints on the oxidation of biogenic $\mathrm{UO}_{2}$ by $\mathrm{Fe}(\mathrm{III})$ (hydr)oxides. Environ. Sci. Technol. 2006, 40 (11), 3544-3550 DOI: 10.1021/ es052305p.

(30) Ulrich, K. U.; Ilton, E. S.; Veeramani, H.; Sharp, J. O.; BernierLatmani, R.; Schofield, E. J.; Bargar, J. R.; Giammar, D. E. Comparative dissolution kinetics of biogenic and chemogenic uraninite under oxidizing conditions in the presence of carbonate. Geochim. Cosmochim. Acta 2009, 73 (20), 6065-6083 DOI: 10.1016/ j.gca.2009.07.012.

(31) Campbell, K. M.; Veeramani, H.; Urich, K.-U.; Blue, L.; Giammar, D.; Bernier-Latmani, R.; Stubbs, J.; Suvorova, E.; Yabusaki, S.; Lezama-Pacheco, J.; Mehta, A.; Long, P. E.; Bargar, J. R. Oxidative dissolution of biogenic uraninite in groundwater at the Old Rifle, CO site. Environ. Sci. Technol. 2011, 45 (20), 8748-8754 DOI: 10.1021/ es200482f.

(32) Maher, K.; Bargar, J. R.; Brown, G. E., Jr. Environmental speciation of actinides. Inorg. Chem. 2013, 52 (7), 3510-3532 DOI: $10.1021 /$ ic301686d.

(33) Tokunaga, T. K.; Kim, Y.; Wan, J.; Yang, L. Aqueous uranium(VI) concentrations controlled by calcium uranyl vanadate precipitates. Environ. Sci. Technol. 2012, 46 (14), 7471-7477 DOI: $10.1021 / \mathrm{es} 300925 \mathrm{u}$.

(34) Campbell, K. M.; Root, R.; O’Day, P. A.; Hering, J. G. A gel probe equilibrium sampler for measuring arsenic porewater profiles and sorption gradients in sediments: II. Field application to Haiwee Reservoir sediment. Environ. Sci. Technol. 2008, 42 (2), 504-510 DOI: $10.1021 /$ es071120a.

(35) Fuller, C. C.; Bargar, J. R.; Davis, J. A.; Piana, M. J. Mechanisms of uranium interactions with hydroxyapatite: Implications for groundwater remediation. Environ. Sci. Technol. 2002, 36 (2), 158-165 DOI: $10.1021 /$ es0108483.

(36) Schofield, E. J.; Veeramani, H.; Sharp, J.; Suvorova, E.; BernierLatmani, R.; Mehta, A.; Stahlman, J.; Webb, S. M.; Clark, D. L.; Conradson, S. D.; Bargar, J. R. Structure of biogenic uraninite produced by Shewanella oneidensis strain MR-1. Environ. Sci. Technol. 2008, 42 (21), 7898-7904 DOI: 10.1021/es800579g.

(37) Shannon, R. D.; Prewitt, C. T. Effective ionic radii in oxides and fluorides. Acta Crystallogr. B 1969, B 25, 925-946 DOI: 10.1107/ s0567740869003220.

(38) Veeramani, H.; Schofield, E. J.; Sharp, J. O.; Suvorova, E. I.; Ulrich, K.-U.; Mehta, A.; Giammar, D. E.; Bargar, J. R.; BernierLatmani, R. Effect of $\mathrm{Mn}(\mathrm{II})$ on the structure and reactivity of biogenic uraninite. Environ. Sci. Technol. 2009, 43 (17), 6541-6547 DOI: $10.1021 / \mathrm{es} 900556 \mathrm{k}$.

(39) Singer, D. M.; Farges, F.; Brown, G. E., Jr. Biogenic nanoparticulate $\mathrm{UO}_{2}$ : Synthesis, characterization, and factors affecting surface reactivity. Geochim. Cosmochim. Acta 2009, 73 (12), 35933611 DOI: 10.1016/j.gca.2009.03.031.
(40) Davis, J. A.; Kent, D. B., Surface Complexation Modeling in Aqueous Geochemistry. Reviews in Mineralogy Vol. 23. In MineralWater Interface Geochemistry; Hochella, M. F., White, A. F., Eds.; Mineralogical Society of America: Chantilly, VA, 1990; pp 177-260.

(41) Gilbert, B.; Huang, F.; Zhang, H. Z.; Waychunas, G. A.; Banfield, J. F. Nanoparticles: Strained and stiff. Science 2004, 305 (5684), 651-654 DOI: 10.1126/science.1098454.

(42) Huang, F.; Gilbert, B.; Zhang, H.; Banfield, J. F. Reversible, surface-controlled structure transformation in nanoparticles induced by an aggregation state. Phys. Rev. Lett. 2004, 92 (15), 155501 DOI: $10.1103 /$ PhysRevLett.92.155501.

(43) McClain, M. E.; Boyer, E. W.; Dent, C. L.; Gergel, S. E.; Grimm, N. B.; Groffman, P. M.; Hart, S. C.; Harvey, J. W.; Johnston, C. A.; Mayorga, E.; McDowell, W. H.; Pinay, G. Biogeochemical hot spots and hot moments at the interface of terrestrial and aquatic ecosystems. Ecosystems 2003, 6 (4), 301-312 DOI: 10.1007/s10021-003-0161-9. 